\title{
AN ALTERNATIVE APPROACH FOR TEACHING THE BASIC DC-DC CONVERTERS BY A GENERALIZATION OF THE BASIC PWM COMMUTATION CELL
}

\author{
Victor Leonardo Yoshimura \\ Electricity and Electronics Department - DAE-E \\ Federal Center of Technological Education of Mato Grosso - CEFET/MT \\ Rua Zulmira Canavarros, 95 - Centro - CEP 78005-390 - Cuiabá - MT - Brazil \\ vlyoshimura@eletro.cefetmt.br
}

\begin{abstract}
This paper proposes a new approach for teaching the basic DC-DC converters, aiming a better understanding of these converters by the student uninitiated in the subject. The proposed strategy is to begin by presenting the basic PWM commutation cell and make a generalization of its characteristics, showing that the buck, boost and buck-boost converters have many similarities. This procedure reduces the number of equations and waveforms to be studied. An interesting effect, only present in the boost converter, is the double region of continuous conduction mode (DRCCM). Simulation results show that the mathematical procedure is consistent and easy for designs.
\end{abstract}

Keywords - Basic DC-DC converters, basic PWM commutation cell, double region of continuous conduction mode, education in Power Electronics, DCM/CCM static gain.

\section{INTRODUCTION}

Teaching the basic DC-DC converters is usually the first step in a switched mode power supplies's (SMPS) course and to reach the static gain equation is crucial in this matter, else it would be pointless to study all other characteristics.

To choose the best strategy to teach these converters is not an easy task, and as many times the subject is taught, more characteristics and approaches are discovered, and a great similarity of equations and waveforms can be observed.

The static gain expressions for the continuous conduction mode (CCM) are simple and well known formulas. The main characteristic is that the static gain depends on the duty cycle only, that is, as long as the load maintains the converter in the CCM, it will not interfere in the gain expression.

The discontinuous conduction mode (DCM) is quite the opposite: the load interferes in the static gain expression. Analysis have been done $[1,2,5,6]$ relating this gain with the load current, and making the CCM/DCM frontier explicit. But if the load is modelled as a pure resistor, which is acceptable in most cases, the static gain expression turns into a function of itself. Instead, it is possible to modify each equation to find and solve a quadratic equation on the duty cycle, with the quality factor as a parameter.

This procedure makes much easier to understand the converters's behaviour, as the gain is written as a function of

Manuscript submited on January $29^{\text {th }}, 2008$; revised March $10^{\text {th }}, 2008$ Recommended by the Editor Fernando L. M. Antunes. the system's inner variables only, especially for the student that studies these circuits for the first time.

After the static gain is obtained, the current and voltage stresses must be found, as they must be, in every design, calculated in order to specify the semiconductors to be used. Also, the PWM commutation cell inductance must be calculated. Those steps complete the basic procedure to design a SPMS's power stage and must be understood by the student.

The proposed approach greatly simplifies the matter, as the equations for each of the basic DC-DC converters show many similarities. This is due to the fact that the commutation cell used in each converter to be the same, that is, the basic PWM commutation cell. From this cell, all the explanation can be done and generalized, reducing the number of equations and waveforms to be studied and, therefore, the cell is proposed as the start point.

This work is organized as follows: firstly, an overview of the PWM commutation cell is done, and then the basic converter's common features and waveforms are studied. In the next section the buck and buck-boost converters are studied, as they show many similarities. Then, the boost converter is studied separately, as it shows a unique effect: the DRCCM, which will be detailed. A section of simulation results follows, which also confirms the developed mathematical procedure. In the final section, some considerations and conclusions are done.

\section{THE BASIC PWM COMMUTATION CELL}

Vorpérian [3,4] studied the PWM switch and identified the basic DC-DC converters's commutation cell, therefore describing each converter's dynamic behaviour. This cell is shown in Figure 1, where the terminals are identified as "active" (a), "passive" (p) and "common" (c).

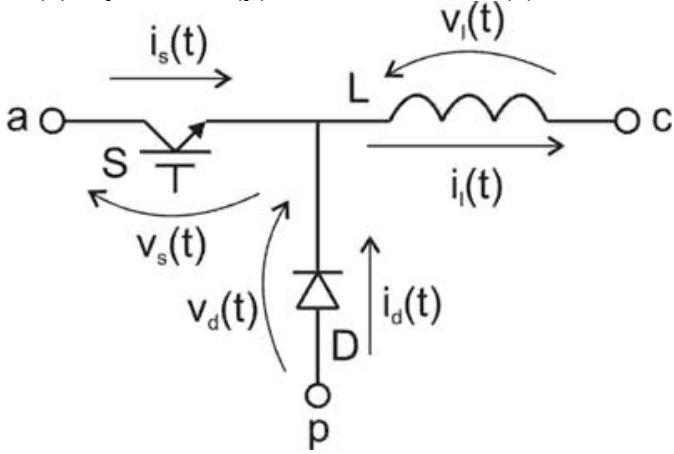

Fig. 1. Basic PWM commutation cell, showing the voltages and currents and their adopted directions. 
In this study, the inductor is considered as a part of the cell. All applied voltages $\mathrm{V}_{\mathrm{ap}}, \mathrm{V}_{\mathrm{cp}}$ and $\mathrm{V}_{\mathrm{ac}}$ are considered $\mathrm{DC}$, and the analysis is done for the steady state. In this case, when the switch (S) is off and how it is well known, there are two possible situations: either the inductor current touches the zero or not. In fact, there is a third possible case: the critical conduction mode, in which the inductor current starts to increase immediately after it touches the zero. This case will be shortly discussed in each converter.

\section{A. Continuous Conduction Mode}

The waveforms for the CCM are shown in Figure 2. It is interesting to note that these waveforms are the same, no matter the converter is the buck, boost or buck-boost. This must be greatly emphasized in the classroom, as it reduces three apparently different groups of waveforms into only one.

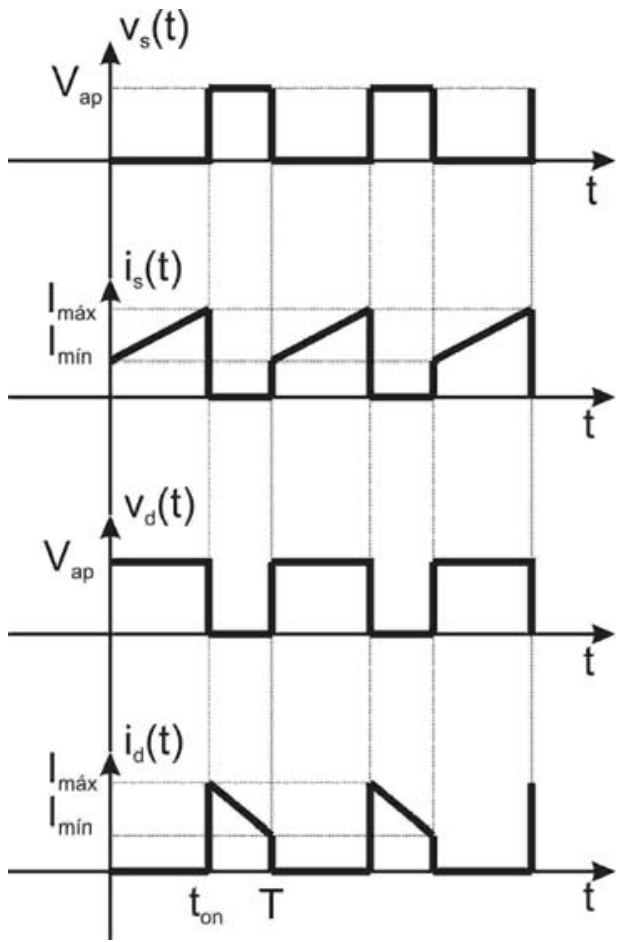

Fig. 2. CCM waveforms for the basic PWM commutation cell.

The inductance is usually specified in terms of maximum allowed inductor current ripple. In this case, the inductance is given by (1).

$$
L=\frac{V_{a c} D}{f \Delta I_{l}}
$$

Where:

$D$ - duty cycle.

$f$ - switching frequency.

$\Delta I_{l}=I_{\text {máx }}-I_{\text {mín }}$ - inductor current ripple.

Not only are the number of waveforms to be taught reduced, but also the currents (average and RMS) and the maximum voltage on the semiconductors. These currents are obtained from the waveforms in figure 2 and given by (2), (3), (4) and (5).

$$
I_{\text {sav }}=D I_{\text {lav }}
$$

$$
\begin{gathered}
I_{\text {srms }}=\sqrt{D\left(I_{l a v}^{2}+\frac{\Delta I_{l}^{2}}{12}\right)} \approx I_{\text {lav }} \sqrt{D} \\
I_{d r m s}=\sqrt{(1-D)\left(I_{\text {lav }}^{2}+\frac{\Delta I_{l}^{2}}{12}\right)} \approx I_{l a v} \sqrt{1-D}
\end{gathered}
$$

Where:

$I_{\text {lav }}$ - inductor average current.

$I_{\text {sav }}$ - switch average current.

$I_{\text {srms }}$ - switch RMS current.

$I_{d a v}$ - diode average current.

$I_{d r m s}$ - diode RMS current.

The approximations made in (3) and (5) are possible due to the fact that, in practical designs, the inductance is chosen so that the ripple becomes much lesser than the average current, that is, $\Delta I_{l}<<I_{\text {lav }}$.

\section{B. Discontinuous Conduction Mode}

The waveforms for the DCM are shown in Figure 3. Again, these waveforms do not depend on the basic DC-DC converter in question

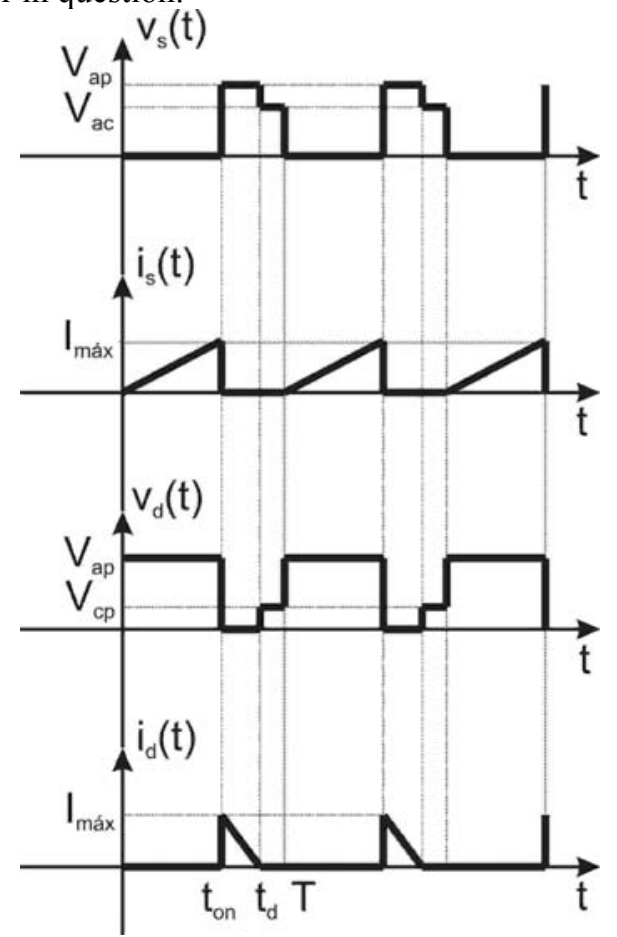

Fig. 3. DCM waveforms for the basic PWM commutation cell.

In the DCM, the ripple and the maximum inductor current are equivalent, that is, $\Delta I_{l}=I_{\text {máx }}$, as the minimum current becomes zero. The currents given in (2) and (3) become (6) and (7), respectively.

$$
I_{\text {sav }}=\frac{V_{a c} D^{2}}{2 f L}
$$




$$
I_{\text {srms }}=\frac{V_{a c} D}{f L} \sqrt{\frac{D}{3}}
$$

In order to find the average and RMS currents in the diode, it is necessary to find the discontinuity time $\left(t_{d}\right)$. From the second operation stage, which is a simple inductor and voltage source loop with nonzero initial current, it is possible to describe $t_{d}$ by $(8)$.

$$
t_{d}=\frac{D}{f}\left(1+\frac{V_{a c}}{V_{c p}}\right)
$$

From (8), it is possible to modify (4) and (5) for the DCM, obtaining then (9) and (10).

$$
\begin{gathered}
I_{d a v}=\frac{V_{a c}^{2} D^{2}}{2 V_{c p} f L} \\
I_{d r m s}=\frac{V_{a c} D}{f L} \sqrt{\frac{D V_{a c}}{3 V_{c p}}}
\end{gathered}
$$

A final remark concerning the basic PWM commutation cell: the maximum voltage on the semiconductors is always equal to $\mathrm{V}_{\mathrm{ac}}$, no matter the converter or the conduction mode.

\section{THE BUCK AND BUCK-BOOST CONVERTERS}

These converters show the same complexity level on their mathematical treatment and due to this they are treated in this section. Despite this, the buck-boost converter should always be taught after the buck and boost converters.

As the static gain is well known for the CCM, the focus will be on the DCM static gain and on the CCM/DCM frontier. In order to do so, the power losses will be neglected and the power balance equation $P_{\text {in }}=P_{o}$ will be used, in which it is always desirable to write the output power as $P_{o}=\frac{V_{o}^{2}}{R}$. Doing so, the load is modelled as a simple resistor. In addition, the basic DC-DC converters's quality factor is defined by (11).

$$
Q=\frac{2 f L}{R}
$$

\section{A. Buck Converter}

The buck converter is shown in Figure 4. It is obtained directly by placing the voltage source between the "a" and "p" terminals and the load between the "c" and "p" terminals.

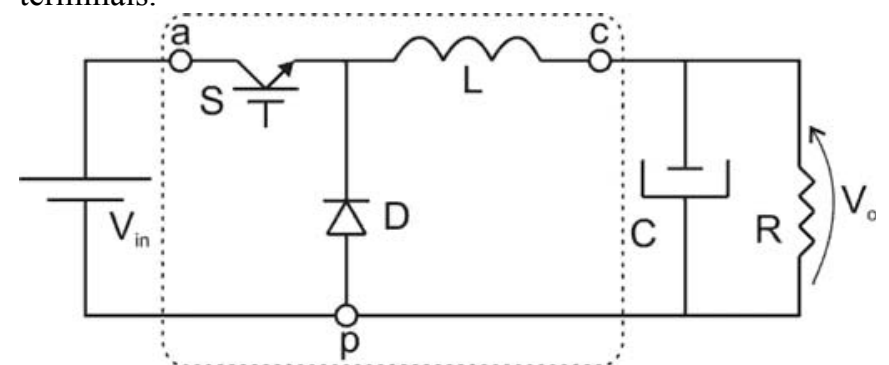

Fig. 4. Buck converter with the basic PWM commutation cell in prominence.
As it can be observed from previous analysis, the maximum voltage on the semiconductors is the input voltage and the average current on the inductor is the average output current.

Proceeding to the DCM static gain determination, the input power is given by (12). Combining (11), (12) and the output power expression, (13) is obtained.

$$
\begin{aligned}
& P_{i n}=V_{i n} \frac{\left(V_{i n}-V_{o}\right) D^{2}}{2 f L} \\
& G^{2}+\frac{D^{2}}{Q} G-\frac{D^{2}}{Q}=0
\end{aligned}
$$

Where:

$G=\frac{V_{o}}{V_{\text {in }}}-$ static gain.

Solving (13) and ignoring the inconsistent solution, (14) is obtained, which represents the DCM static gain for the buck converter.

$$
G=\frac{D^{2}}{2 Q}\left(-1+\sqrt{1+\frac{4 Q}{D^{2}}}\right)
$$

In order to find the critical duty cycle, that is, the duty cycle in which the converter operates at the critical conduction mode, (14) is made equal to the duty cycle, which is the CCM static gain. Then (15) is obtained and the graph in Figure 5 is plotted.

$$
D_{c r}=1-Q
$$

Where:

$D_{c r}$ - critical duty cycle

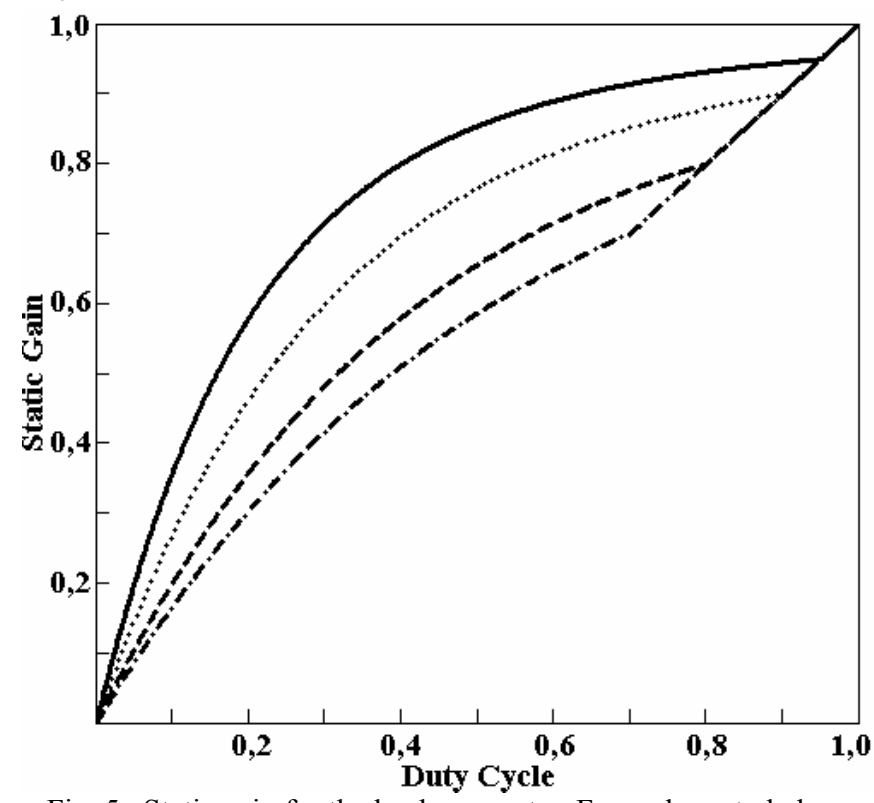

Fig. 5. Static gain for the buck converter. From above to below: $\mathrm{Q}=0,05, \mathrm{Q}=0,1, \mathrm{Q}=0,2$ and $\mathrm{Q}=0,3$.

Figure 5 shows the static gain as a function of the duty cycle. It is interesting to note that if the quality factor is equal or greater than the unity, then the buck converter operates at the CCM for any duty cycle. 


\section{B. Buck-Boost Converter}

Figure 6 shows the buck-boost converter which, from the basic PWM commutation cell point of view, is obtained by placing the input voltage between the "a" and "c" terminals, while the output is placed between the " $c$ " and "p" terminals.

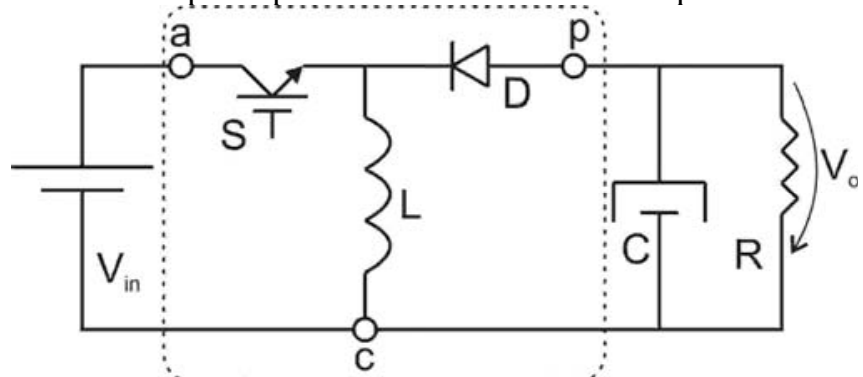

Fig. 6. Buck-boost converter with the basic PWM commutation cell in prominence.

Considering previous analysis, and observing Figure 6, the maximum voltage on the semiconductors is the sum of input and output voltages and the average current on the inductor is the sum of input and output average currents.

The input power is given by (16). Combining (11), (16) and the output power expression, the DCM static gain in (17) is obtained.

$$
\begin{gathered}
P_{i n}=\frac{V_{i n}^{2} D^{2}}{2 f L} \\
G=\frac{D}{\sqrt{Q}}
\end{gathered}
$$

Again, in order to find the critical duty cycle, (17) must be made equal to $\frac{D}{1-D}$, which is well known to be the CCM static gain for the buck-boost converter. Then (18) is obtained and the graph in Figure 7 is plotted.

$$
D_{c r}=1-\sqrt{Q}
$$

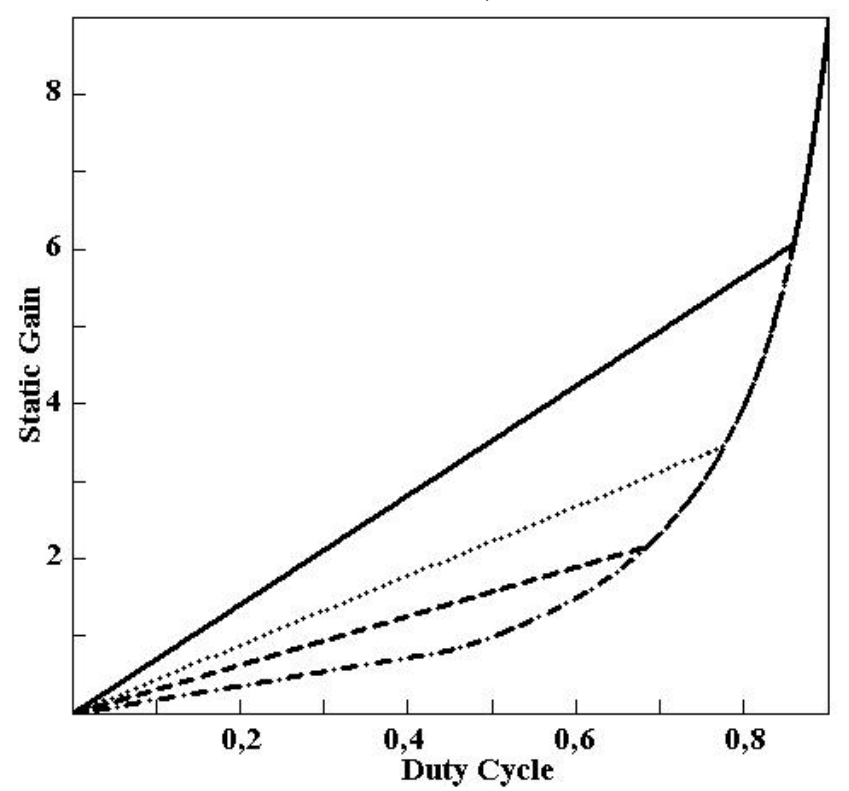

Fig. 7. Static gain for the buck-boost converter. From above to below: $\mathrm{Q}=0,02, \mathrm{Q}=0,05, \mathrm{Q}=0,1$ and $\mathrm{Q}=0,3$.
It is very interesting to observe that, like in the buck converter, the buck-boost converter will always operate in the CCM if the quality factor is equal or greater than the unity, no matter the duty cycle.

\section{THE BOOST CONVERTER AND THE DRCCM EFFECT}

The boost is the only converter that shows the DRCCM effect and due to this, it is put in this section separately. Figure 8 shows the boost converter, which, from the basic PWM commutation cell point of view, is obtained by placing the input between the "a" and "c" terminals, while the output is placed between the "a" and " $p$ " terminals. Observing the converter, it can be said that the boost converter is the buck backwards, as the output voltage is switched to the input (the buck converter switches the input voltage to the output).

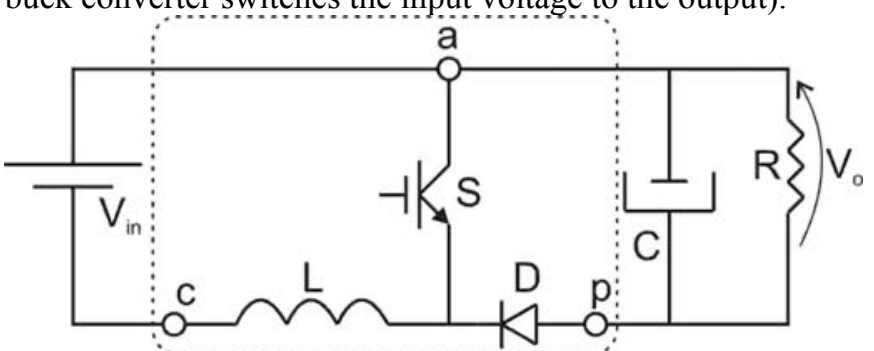

Fig. 8. Boost converter with the basic PWM commutation cell in prominence.

In order to clearly show the commutation cell, the boost converter in Figure 8 was drawn in a different way than that one that is seen in most bibliographies. Then, it is possible to see that the maximum voltage on the semiconductors is the output voltage and the average current on the inductor is the input current.

Adopting the same method used in the previous converters leads to a cubic equation, which becomes harder to solve. Then, the procedure to obtain the DCM static gain for the boost converter will be modified. The average output current in the boost converter is the average diode current. From (9), this current is calculated as in (19):

$$
I_{\text {dav (boost) }}=I_{o}=\frac{V_{\text {in }}^{2} D^{2}}{2\left(V_{o}-V_{\text {in }}\right) f L}
$$

As $I_{o}=\frac{V_{o}}{R},(20)$ is obtained by modifying (19).

$$
G^{2}-G-\frac{D^{2}}{Q}=0
$$

Solving (20) and discarding the inconsistent solution, (21) is obtained, which is the DCM static gain for the boost converter.

$$
G=\frac{1}{2}\left(1+\sqrt{1+\frac{4 D^{2}}{Q}}\right)
$$

To find the critical duty cycle, (21) must be made equal to $\frac{1}{1-D}$, which is the $\mathrm{CCM}$ static gain for the boost converter. Then, (22) is obtained. 


$$
D_{c r}^{3}-2 D_{c r}^{2}+D_{c r}-Q=0
$$

The roots of this cubic are the critical duty cycles. It can be observed from (22) and Figure 9 that the quality factor only moves the cubic curve up and down, or, more precisely, as the quality factor increases, the more the curve goes down. The curve has a local minimum point at $D=1$ and a local maximum point at $D=\frac{1}{3}$. Obviously, the quality factor is a positive quantity, which forces one of the roots to be greater than the unity and, therefore, to be discarded as a solution.

While the polynomial, calculated at its maximum, stays above zero, the polynomial has two roots in the interval $[0,1]$, that is, the converter has two critical duty cycles. The condition for this to happen is that $Q<\frac{4}{27}$.

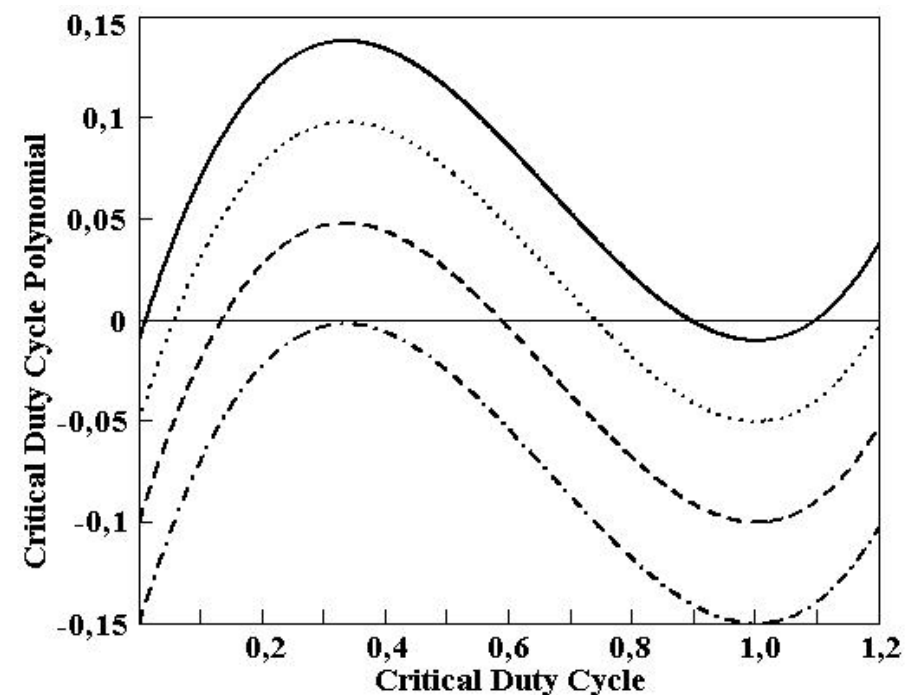

Fig. 9. Critical duty cycle polynomial in (22) for different values of quality factor. From above to below: $\mathrm{Q}=0,01, \mathrm{Q}=0,05, \mathrm{Q}=0,1$ and $\mathrm{Q}=0,15$.

This is the DRCCM, which is a very curious effect. For the condition stated previously, the conduction modes are as follows:

$$
\left\{\begin{array}{lll}
D<D_{\text {crs }} & \Rightarrow & \mathrm{CCM} \\
D_{c r s}<D<D_{\text {crg }} & \Rightarrow & \mathrm{DCM} \\
D>D_{\text {crg }} & \Rightarrow & \mathrm{CCM}
\end{array}\right.
$$

Where:

$D_{c r s}$ - smaller critical duty cycle

$D_{c r g}$ - greater critical duty cycle

The DRCCM should be greatly emphasized when teaching SPMS's Control Fundamentals, as the transfer function of each converter is affected by the conduction mode [3,4]. Still concerning this matter, some duty cycle range limiting circuits should be presented to show the student some ways to avoid the boost converter going into the other conduction mode, which could ruin the designed control strategy.

Observing (21), the CCM static gain and the critical duty cycles, Figure 10 is plotted.

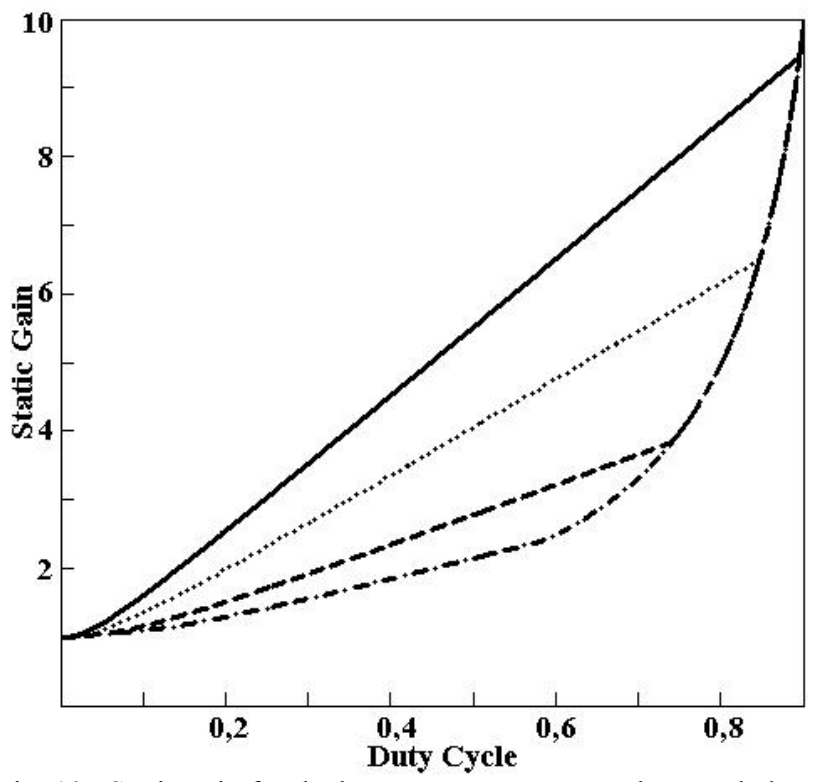

Fig. 10. Static gain for the boost converter. From above to below: $\mathrm{Q}=0,02, \mathrm{Q}=0,05, \mathrm{Q}=0,1$ and $\mathrm{Q}=0,3$.

\section{SIMULATION RESULTS}

Simulations were done using Pspice in order to verify the developed theory and the converters were drawn as ideal as possible, as this work deals with basic theory to be taught to undergraduate students. Of course, some non-idealities must be inserted when simulating real SPMS's designs.

All simulations were done using the following parameters: $V_{\text {in }}=180 \mathrm{~V}, f=50 \mathrm{kHz}$ and $L=416,7 \mu \mathrm{H}$. The Sbreak component was used as the switch and the Dbreak as the diode. The duty cycle was varied from 0,05 to 0,9 in steps of 0,05 .

\section{A. Buck Converter}

Three groups of simulations were done for quality factors of $0,1,0,2$ and 0,3 . With the obtained output voltages, the simulated static gain curve was plotted as in Figure 11.

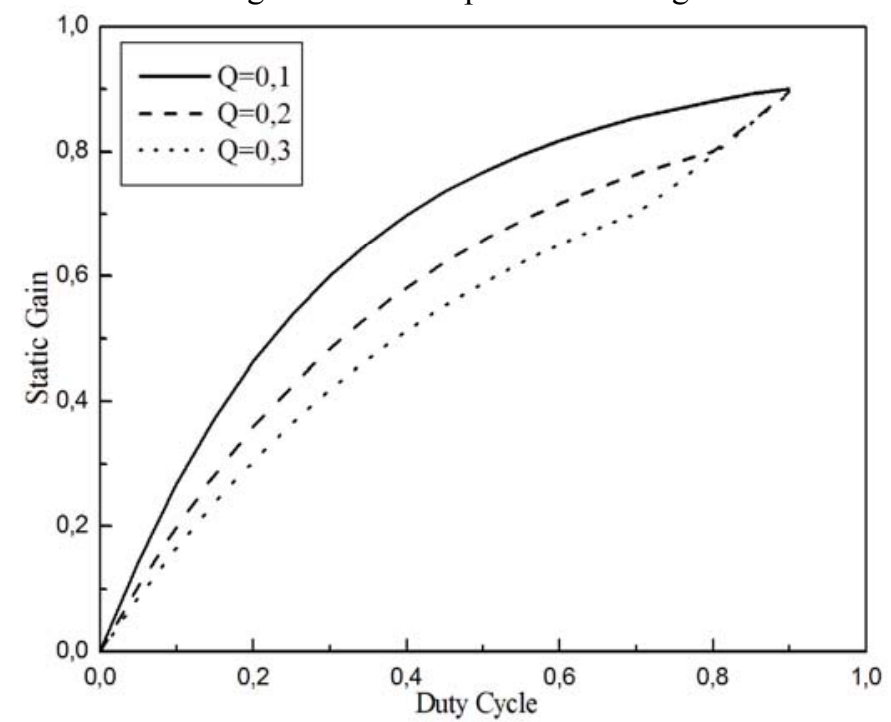

Fig. 11. Simulated static gain as a duty cycle function, with the quality factor as a parameter, for the buck converter. 
For a quality factor of 0,3 , the inductor current waveforms are in Figure 12. Note that according to (15), the critical duty cycle is 0,7 , which is confirmed by this simulation.

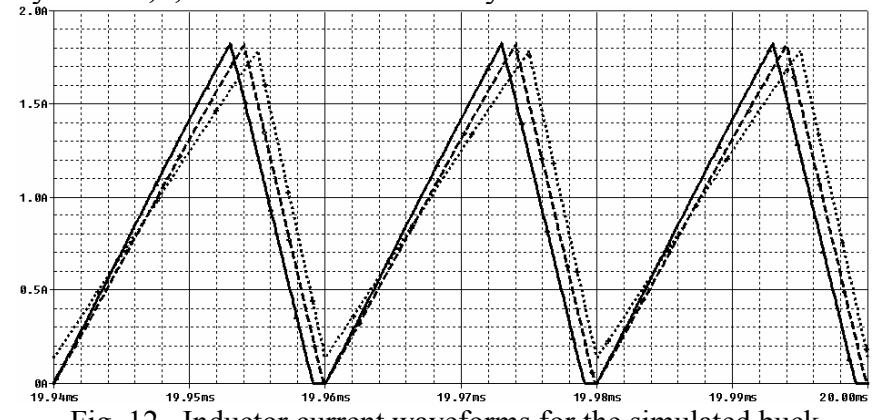

Fig. 12. Inductor current waveforms for the simulated buck converter $(\mathrm{Q}=0,3)$. $\mathrm{D}=0,65$ (solid), $\mathrm{D}=0,7$ (dash) and $\mathrm{D}=0,75$ (dot).

\section{B. Boost Converter}

Three groups of simulations were simulated for quality factors of $0,02,0,05$ and 0,1 . Like in the buck converter, the simulated static gain was plotted as in Figure 13.

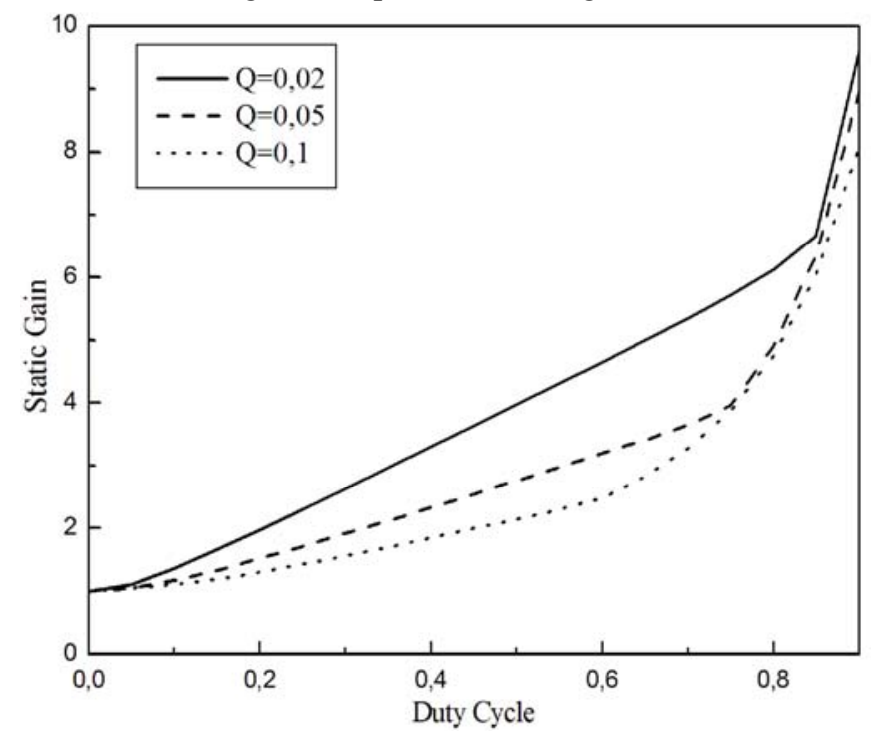

Fig. 13. Simulated static gain as a duty cycle function, with the quality factor as a parameter, for the boost converter.

Figure 13 shows a great similarity with Figure 10, except for duty cycles near the unity, due to the very high static gain.

For a quality factor of 0,1 the inductor current waveforms are in figures 14 and 15 . This quality factor was chosen in order to show the DRCCM effect. According to (22), the critical duty cycles are 0,133 and 0,587 , which is confirmed by this simulation.

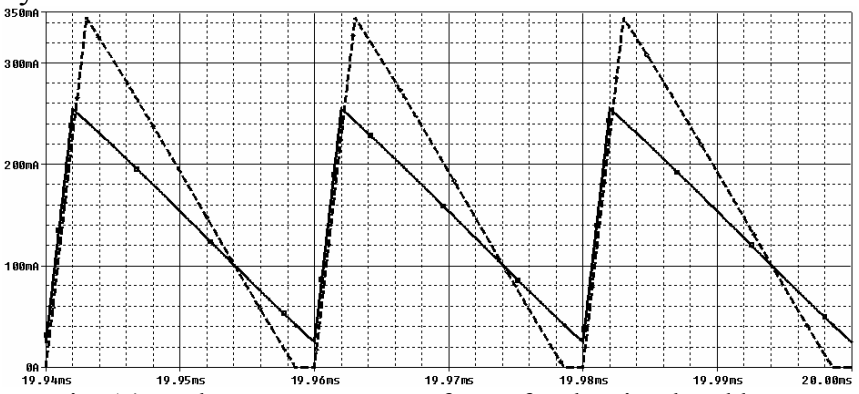

Fig. 14. Inductor current waveforms for the simulated boost converter $(\mathrm{Q}=0,1)$. $\mathrm{D}=0,1$ (solid) and $\mathrm{D}=0,15$ (dash).

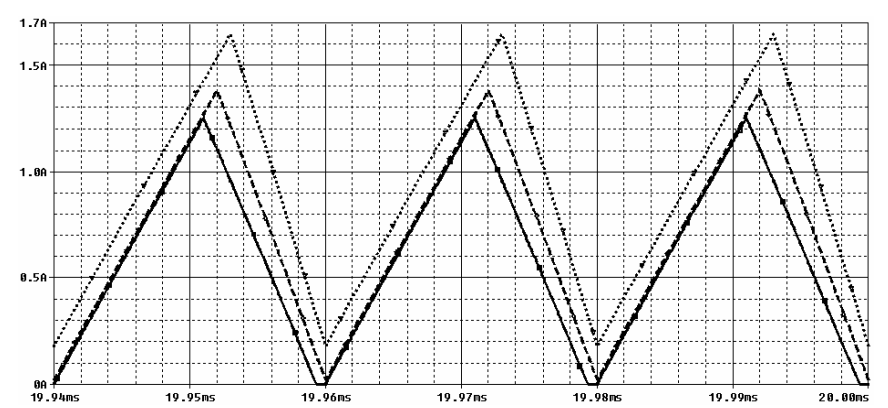

Fig. 15. Inductor current waveforms for the simulated boost converter $(\mathrm{Q}=0,1)$. $\mathrm{D}=0,55$ ( solid), $\mathrm{D}=0,6$ (dash) and $\mathrm{D}=0,65$ (dot).

\section{Buck-Boost Converter}

Like in previous simulations, three groups were simulated. The chosen quality factors were $0,05,0,1$ and 0,3 . The simulated static gain is plotted in Figure 16.

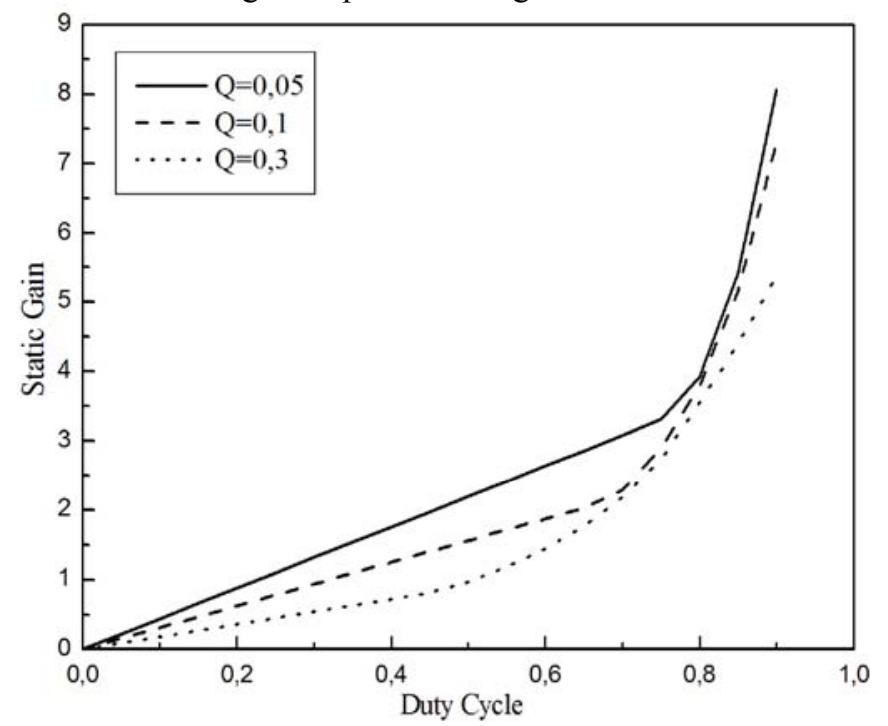

Fig. 16. Simulated static gain as a duty cycle function, with the quality factor as a parameter, for the buck-boost converter.

Again, like in the boost converter, there is a difference between theoretical (Figure 7) and simulated (Figure 16) values for duty cycles near the unity due to the very high static gain, which is comparable to the boost converter's static gain (Figure 10).

For the quality factor of 0,3 , the inductor current waveforms are in Figure 17. Note that according to (18), the critical duty cycle is 0,45 , which is confirmed by this simulation.

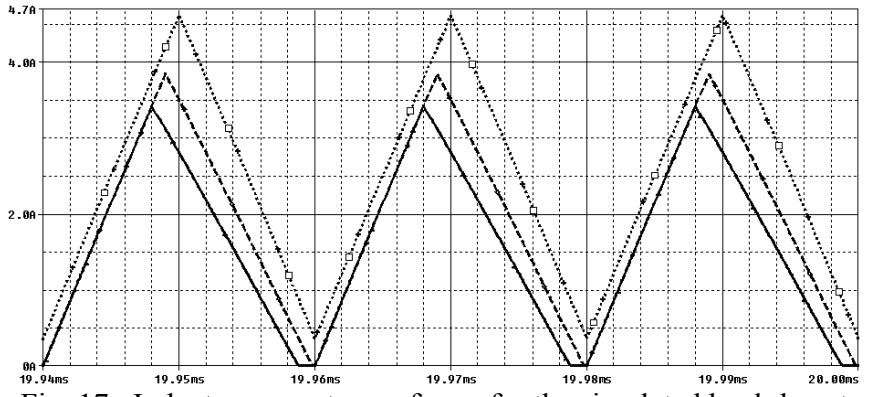

Fig. 17. Inductor current waveforms for the simulated buck-boost converter $(\mathrm{Q}=0,3)$. $\mathrm{D}=0,4$ (solid), $\mathrm{D}=0,45$ (dash) and $\mathrm{D}=0,5$ (dot). 


\section{CONCLUSIONS}

The proposed procedure showed important advantages to teach the basic DC-DC converters, such as simplification of equations and reduction of the number of equations and waveforms to be studied.

This approach can also be done for other DC-DC converters, like the forward, flyback, etc., as they are derived from the basic DC-DC converters. In order to do this, the equations must be reformulated for each converter. This should simplify matters to teach and learn all DC-DC converters based on the basic PWM commutation cell.

It must be emphasized that this approach should not be used solely. It must be associated to other mentioned approaches, such as those contained in classical books.

The simulation results confirmed the theoretical expressions, except at high gains for the boost and buckboost converters. This is due to the well known fact that, even in the CCM, the static gain is still a function of the load $[1,2,5]$.

The DRCCM effect in the boost converter was studied and described and its effects should be always presented, especially for graduation students, as the boost converter could enter the CCM at low duty cycles for low quality factors and this would modify the transfer function. The DRCCM effect existence was proved both theoretically and by simulation.

Further researches should focus on the development of a didactic kit exploring the presented concepts, in order to build a three-in-one converter. Another point is to develop the equations to include some non-idealities, which could be useful in a second SMPS course.

\section{ACKNOWLEDGEMENTS}

The author would like to thank his colleague Dr. Valtemir Emerencio do Nascimento for reviewing the manuscript and giving suggestions.

\section{REFERENCES}

[1] L. F. P. de Mello, Análise e Projeto de Fontes Chaveadas. $1^{\text {st }}$ ed. Érica, São Paulo, 1996.

[2] I. Barbi, D. C. Martins, Eletrônica de Potência: Conversores $\mathrm{CC}-\mathrm{CC}$ Básicos Não Isolados. $1^{\text {st }}$ ed. Author's Edition, Florianópolis, 2000.

[3] V. Vorpérian, "Simplified Analysis of PWM Converters Using Model of PWM Switch - Part I: Continuous Conduction Mode" IEEE Transactions on Aerospace and Electronic Systems, vol. 26, n. 3, May 1990.

[4] V. Vorpérian, "Simplified Analysis of PWM Converters Using Model of PWM Switch - Part II: Discontinuous Conduction Mode" IEEE Transactions on Aerospace and Electronic Systems, vol. 26, n. 3, May 1990.

[5] N. Mohan, T. M. Undeland, W. P. Robbins, Power Electronics: Converters, Applications and Design. John Wiley \& Sons, $2^{\text {nd }}$ edition, New York, 1995.

[6] M. H. Rashid, Eletrônica de Potência: Circuitos, Dispositivos e Aplicações. $1^{\text {st }}$ ed. Makron Books, São Paulo, 1999.

\section{BIOGRAPHY}

Victor Leonardo Yoshimura was born in Campo Grande, Mato Grosso do Sul, Brazil on May $3^{\text {rd }}, 1977$. He obtained his Electrical Engineer and Master in Electrical Engineering degrees from UFMS in 1999 and UFSC in 2002, respectively.

He was with Spectro Engenharia e Sistemas Eletrônicos as a development engineer from 2002 until 2003. From 2003 to 2005, he was with Uniderp as a Power Electronics professor. Since 2005, he is with CEFET/MT as a Power Electronics professor of the Industrial Automation Technology course. His interests include ballasts, UPS's, DC-DC converters and control of SMPS's. 